\title{
Trass Effect as a Source of Silicon on Soil, Hay, Husk and Growth of Rice Plants
}

\author{
Mirawanty Amin ${ }^{1, *}$, Rahadian Adi Prasetyo ${ }^{2}$, Chandra Padang ${ }^{2}$ \\ ${ }^{1}$ Assessment Institute For Agricultural Technology of North Celebes, Kampus Pertanian Kalasey \\ Street, Manado 95013 North Celebes \\ ${ }^{2}$ Bogor Agricultural University, Kampus IPB Dramaga Street 16680 West Java
}

\begin{abstract}
Silicon (Si) is one of the important things for rice growth. The importance of $\mathrm{Si}$ relates to increased rice yield, increased resistance to disease and resistance to falling. The rice is an accumulator plant of $S i$ which requires $S i$ for its growth. However, the $S i$ in soil is continually decreased therefore the additional $S i$ is needed intothe soil. Trass is one of the natural materials containing $\mathrm{Ca}$ and $\mathrm{Si}$, therefore it can be used as a $\mathrm{Si}$ fertilizer. This study aims to determine levels of soil $\mathrm{Si}$, straw, husk, and growth in rice. This research consisted of three types of soil, Oxisol, Inceptisol and Vertisol as the main plot and 7 doses of burnt fuel namely $0\left(\mathrm{D}_{0}\right) ; 1.25\left(\mathrm{D}_{1}\right) ; 2.5\left(\mathrm{D}_{2}\right)$; $3.75\left(\mathrm{D}_{3}\right) ; 5\left(\mathrm{D}_{4}\right) ; 7.5(\mathrm{D} 5) ; 10(\mathrm{D} 6) \mathrm{g} \mathrm{kg}^{-1}$ of soil as subplots. The treatment which is using in this research is a combination of the two factors and repeated 3 times 63 unit experiments were obtained. The results showed the Trass significant concerning to $\mathrm{Si}$ in the husk and $\mathrm{Si}$ of the soil. Vertisol gives the highest number of panicles of 27 and $\mathrm{Si}$ in the straw of $12.75 \mathrm{mg}$ $\mathrm{kg}^{-1}$.
\end{abstract}

\section{Introduction}

Rice (Oryza sativa L.) is one type of food plant which has the important role in Indonesia society, therefore the need for rice in Indonesia has increased from year to year along with the increasing population. The consumption of rice per capita in Indonesia necessary is around $111.58 \mathrm{~kg}$ year ${ }^{-1}$, in order that 29.13 million tons of rice is essential by Indonesia each year [1].

Many efforts have been made to meet domestic demand for rice. In other hand, several problem cause the need for rice itself not to be fulfilled. The conversion of agricultural land to non-agricultural land [2] and land degradation causes macro and micronutrients as well as beneficial elements such as low $\mathrm{Si}$ so it does not support rice growth [3]. Rice needs $\mathrm{Si}$ in its growth because as much as $230-470 \mathrm{~kg} \mathrm{ha}-1 \mathrm{Si}$ is needed by rice per plant [4]. In other hand, rice soils generally have a low $S i$ content $[5,6]$. This can be proven by seeing farmers the erosion of nutrients land use without proper management practices, resulting in depletion of losses in soil and resulting in reduced yields [7, 8, 9]. Si has an important role in rice, increasing plant resistance to disease, stress or environmental stress to disease, and reducing metal toxicity $[11,12,13,14,15]$.

\footnotetext{
*Corresponding author: mirawantyamin@gmail.com
} 
This shows that $S i$ can be an element essential needed for rice growth and production [16]. Currently, $S i$ ranks fourth as the most important nutrient for rice in rice-producing countries in Southeast Asia after N, P, and K [17]. In hence, the management efforts are needed to which can restore or maintain levels therefore the remaining harvest is in the form of husks and straw or the addition of $S i$ fertilizer $[18,19]$. One thing which can be used as $S i$ fertilizer is Trass.

Trass is formed from weathering of volcanic rocks which are rich in feldspar and silica [20]. Indonesia has many areas which hold Trass potentials such as Bogor, Nagrek, Yogyakarta, and Pekalongan. Trass is also available outside Java Island such as Gianyar, Lampung, Flores Island, Minahasa in North Sulawesi, and Southeast Sulawesi [21].

It is usually used as a building block for concrete therefore other functions of trass which can be used as fertilizer for $S i$ have not yet been widely used. In this study, the trass test was carried out as a source of $S i$ and its effect on plant growth.

\section{Materials and Methods}

\subsection{Place and time of research}

The research was conducted at the Laboratory of Chemistry and Soil Fertility apart from that it was also done the Greenhouse of the Cikabayan Experimental Garden, Department of Soil and Land Resources, Faculty of Agriculture, Bogor Agricultural University. The research for seven months from January to September 2017.

\subsection{Materials and Tools}

The materials used were three types of wetland Oxisol from Mount Sindur, Inceptisol from Ciampea Bogor, and Vertisol from Cihea Cianjur [9]. The trass used comes from Ciampea Bogor which is combined with $\mathrm{CaCO} 3$ as a source of silica fertilizer. The basic fertilizers used are urea, SP-36, $\mathrm{KCl}$, and other materials for analysis in the laboratory.

\subsection{Research procedure}

The greenhouse experiment done used a factorial randomized block design consisting of two factors. The first factor is three types of soil, namely Oxisols (S1), Inceptisols (S2), and Vertisols (S3). The second factor consists of seven levels of trass burn dose, namely control (D0); 1.25 (D1); 2.5 (D2); 3.75 (D3); 5 (D4); 7.5 (D5); 10 (D6) g kg-1 and repeated three times to obtain 63 experimental units. Greenhouse experiments were carried out to determine the effect of trass on plant result, namely the number of panicles, Si content in the soil, husks, and straw.

Air-dry the soil from the field while mashing it until it passes the $5 \mathrm{~mm}$ sieve. Furthermore, the soil is weighed $5 \mathrm{~kg}$ absolute dry weight (BKM) and put in a bucket, then the trass is given into the bucket according to the treatment dose and stirred until it is evenly grounded. Subsequently incubated for seven days in the inundation conditions $\pm 5 \mathrm{~cm}$. After the incubation period ends, followed by is carried out.

\subsection{Planting and Maintenance}

For 20 days old, 3 seeds are planted in each pot. The basic fertilizers given are Urea, SP-36, and $\mathrm{KCl}$ which is supplied according to the recommended dosage, namely $0.6 \mathrm{~g}$ Urea $\mathrm{kg}-1$, $0.2 \mathrm{~g} \mathrm{SP}-36 \mathrm{~kg}-1$, and $0.2 \mathrm{~g} \mathrm{KCl} \mathrm{kg}-1$. Urea and $\mathrm{KCl}$ were given three times, namely at 
planting time, $2 \mathrm{MST}$, and maximum vegetative time (10 MST). SP-36 is given once during planting. Stagnant water conditions of $\pm 5 \mathrm{~cm}$ were maintained throughout the experiment. Weeding is done manually to weeds are found by removing them. Pest control is carried out as necessary with insecticide beta siflurine. At $10 \mathrm{WAP}$ measurements were taken to calculate the number of tillers and plant height.

\subsection{Harvest}

Harvesting is done when the rice reaches the yellow cooking criteria, namely $90 \%$ of the panicles have turned yellow. This condition is reached about 35 days after flowering, which is 120 days. Harvesting is done by cutting the rice stalks just above the soil surface, the grain is knocked down, weighed and dried to get the weight of milled dry grain.

\section{Result and Discussion}

Soil analysis was carried out to determine nutrient levels in the soil before being applied the treatment (Table 1). The analysis showed that the three types of soil had different levels of Si Oxisol 22.32 ppm, Inceptisol 49 ppm, and Vertisol 74.69 ppm.

Table 1. Soil analysis results for Oxisol, Inceptisol and Vertisol

\begin{tabular}{|c|c|c|c|c|c|}
\hline Soil Properties & Unit & Method & Oxisol & Inceptisol & Vertisol \\
\hline $\mathrm{pH} \mathrm{H} 2 \mathrm{O}$ & - & pH Meter & 5.35 & 5.4 & 5.04 \\
\hline $\mathrm{P} 2 \mathrm{O} 5$ & ppm & Bray 1 & 15.44 & 1.17 & 14.82 \\
\hline Si Tersedia & ppm & NH4OAc pH 4.8 & 22.32 & 49.00 & 74.69 \\
\hline KTK & $\operatorname{cmol}(+) \mathrm{kg}^{-1}$ & $N$ NH4OAc pH 7.0 & 17.48 & 25.06 & 47.55 \\
\hline Ca-dd & $\operatorname{cmol}(+) \mathrm{kg}^{-1}$ & $N$ NH4OAc pH 7.0 & 4.05 & 8.99 & 13.25 \\
\hline Mg-dd & $\mathrm{cmol}(+) \mathrm{kg}^{-1}$ & $N$ NH4OAc pH 7.0 & 0.92 & 2.51 & 1.35 \\
\hline K-dd & $\operatorname{cmol}(+) \mathrm{kg}^{-1}$ & $N$ NH4OAc pH 7.0 & 0.35 & 0.92 & 1.34 \\
\hline Na-dd & $\operatorname{cmol}(+) \mathrm{kg}^{-1}$ & $N$ NH4OAc pH 7.0 & 0.56 & 0.71 & 1.02 \\
\hline C-Organik & $\%$ & Walkley \& Black & 2.96 & 1.51 & 1.96 \\
\hline N-Total & $\%$ & Kjehdahl & 0.21 & 0.16 & 0.24 \\
\hline Al-dd & $\operatorname{cmol}(+) \mathrm{kg}^{-1}$ & $\mathrm{~N} \mathrm{KCl}$ & 0.56 & Ns & $\mathrm{ns}$ \\
\hline H-dd & $\operatorname{cmol}(+) \mathrm{kg}^{-1}$ & $\mathrm{~N} \mathrm{KCl}$ & $\mathrm{ns}$ & 0.11 & 0.11 \\
\hline $\mathrm{Fe}$ & ppm & DTPA & 19.33 & 23.42 & 177.12 \\
\hline $\mathrm{Cu}$ & ppm & DTPA & ns & 2.13 & 9.09 \\
\hline $\mathrm{Zn}$ & ppm & DTPA & ns & 3.42 & 7.14 \\
\hline $\mathrm{Mn}$ & ppm & DTPA & ns & 61.15 & 93.70 \\
\hline
\end{tabular}

ns $=$ not set

The results of the analysis of variance showed that the soil type had no significant effect on the number of panicles $10 \mathrm{MST}$, while the type of soil combined with trass too no significant effect. The Duncan test results stated that the effect of trass and soil type on the number of panicles (Table 2) showed that the number of panicles in Vertisol (S3) was higher than Oxisol (S1) and Inceptisol (S2). The presence of Si is sufficient to strengthen the stems, help form panicles, increase the number of panicles and the percentage of ripe rice grains, and maintain upright leaves [22]. Vertisols with high Si content in the soil and coupled with trass as the Si source help to increase plant growth. Oxisol is a type of soil which has undergone further weathering and has a limiting factor, namely the low level of soil fertility [23]. This is evidenced by the results of the initial soil analysis (Table 1), Oxisols have a lower 
fertility rate than other soil types. Inceptisol is soil with moderate Si nutrient content which has Mn content of $61.15 \mathrm{ppm}, \mathrm{Fe} 23.42 \mathrm{ppm}$ (Table 1). This is thought to be a limiting factor in rice growth.

Table 2. Effect of trass and soil type on plant height at 10 WAP

\begin{tabular}{|l|c|c|c|c|c|c|c|c|c|}
\hline \multirow{2}{*}{ Treatment } & $\mathbf{D}_{\mathbf{0}}$ & $\mathbf{D}_{\mathbf{1}}$ & $\mathbf{D}_{\mathbf{2}}$ & $\mathbf{D}_{\mathbf{3}}$ & $\mathbf{D}_{\mathbf{4}}$ & $\mathbf{D}_{\mathbf{5}}$ & $\mathbf{D}_{\mathbf{6}}$ & Average \\
\cline { 2 - 9 } & $\ldots \ldots \ldots \ldots \ldots \ldots \ldots \ldots \ldots \ldots \ldots$ & $\ldots \ldots \ldots \ldots \ldots \ldots \ldots \ldots \ldots \ldots \ldots \ldots \ldots \ldots \ldots \ldots \ldots \ldots \ldots \ldots \ldots \ldots \ldots \ldots \ldots \ldots$ \\
\hline S1 (Oxisol) & 21 & 11 & 15 & 18 & 15 & 19 & 25 & $18 \mathrm{a}$ \\
\hline S2 (Inceptisol) & 17 & 13 & 14 & 9 & 14 & 11 & 18 & $14 \mathrm{a}$ \\
\hline S3 (Vertisol) & 24 & 30 & 24 & 28 & 31 & 29 & 25 & $27 \mathrm{~b}$ \\
\hline Average & $21 \mathrm{a}$ & $18 \mathrm{a}$ & $18 \mathrm{a}$ & $18 \mathrm{a}$ & $20 \mathrm{a}$ & $19 \mathrm{a}$ & $22 \mathrm{a}$ & \\
\hline
\end{tabular}

The results of variance analysis showed that soil type had no significant effect on rice straw Si content, while soil type combined with trass too no significant effect. The Duncan test results stated that Vertisol (S3) had the highest $S i$ content in straw compared to the other two soils (Table 3). Si content in rice straw ranges from 4-20\% [24]. This is the result of the Si analysis carried out on the husks. In addition it can be seen that in Vertisol (S3), the increase in each dose of trass given also making the increase of $S i$ level in the straw. The provision of adequate $S i$ fertilizers causes an increase in the absorption of $S i$ by rice and subsequently, the Si content in straw also increase [25].

In addition, it can be seen that in Vertisol (S3), the increase in each dose of trass given, the $\mathrm{Si}$ level in the straw also increase. The provision of adequate Si fertilizers causes an increase in the absorption of Si by rice and subsequently, the Si content in straw also increases [25].

Table 3. Effect of trass and soil type on plant height at $10 \mathrm{WAP}$

\begin{tabular}{|c|c|c|c|c|c|c|c|c|}
\hline \multirow[t]{2}{*}{ Treatment } & $\mathbf{D}_{\mathbf{0}}$ & $\mathbf{D}_{1}$ & $\mathbf{D}_{2}$ & $\mathbf{D}_{3}$ & $\mathbf{D}_{4}$ & $\mathbf{D}_{5}$ & $\mathbf{D}_{6}$ & Average \\
\hline & \multicolumn{8}{|c|}{ 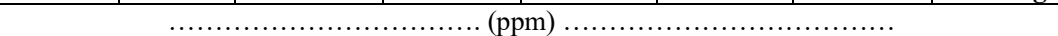 } \\
\hline S1 (Oxisol) & 11.43 & 10.87 & 10.83 & 11.17 & 11.63 & 11.87 & 11.43 & $11.31 \mathrm{~b}$ \\
\hline S2 (Inceptisol) & 7.07 & 5.77 & 7.63 & 7.77 & 8.03 & 8.63 & 7.17 & $7.43 \mathrm{a}$ \\
\hline S3 (Vertisol) & 11.77 & 10.37 & 12.33 & 12.50 & 13.87 & 13.97 & 14.50 & $12.754 \mathrm{c}$ \\
\hline Average & $10.08 \mathrm{~b}$ & $9 \mathrm{a}$ & $10.26 \mathrm{~b}$ & $10.47 \mathrm{~b}$ & $11.17 \mathrm{~b}$ & $11.48 \mathrm{~b}$ & $11.03 \mathrm{~b}$ & \\
\hline
\end{tabular}

The results of the variance analysis showed that there was an interaction between soil type and trass against $S i$ in rice husks. However, it can be seen that Vertisol has a lower $S i$ content in the husk. This can be caused by the very high $\mathrm{Fe}$ content in Vertisols compared to the other two types of soil. The rice husk is usually around $10 \%$, but in this study, it produced up to $38.77 \%$, therefore the return of plant residues to the soil can help restore $S i$ which has been lost during planting $[26,27,28]$. The harvest of 5 tons of grain ha-1, 4.5 tons of straw and husks covers $30 \%$ of the grain weight, in hence in one harvest in the rice fields of Lembur Leutik hamlet (behind the Darmaga IPB campus, West Java) $971 \mathrm{~kg}$ of $\mathrm{SiO}_{2}$ will be transported ha- ${ }^{-1}$ [29]. The $\mathrm{SiO}_{2}$ content of husk and rice straw in this area was 21.23 and $16.01 \%$.

Based on table 4, it can be seen that the increasing dose of trass, the higher Si content in the soil. Increasing the dose of trass increases the available soil $\mathrm{Si}$ because the $\mathrm{H}_{4} \mathrm{SiO}_{4}$ from the trass dissolves into the soil, so the soil $\mathrm{Si}$ concentration increases. This proves that $\mathrm{Si}$ fertilization is needed in rice fields in Indonesia. As previously known, $\mathrm{Si}$ is a very abundant element in the soil with a range of 25 to $35 \%$, repeated planting without the addition or addition of Si can reduce the available soil Si content [29]. In Indonesia, the soil Si content is lower in rice fields that are intensively planted where the very large Si uptake is not followed by a return of harvest residues or the addition of fertilizers [3]. 
Table 4. Effect_of trass and soil type on Si soil and husks

\begin{tabular}{|c|l|l|}
\hline Treatment & Husk Si & Soil Si \\
\hline S1T1D0 & $36.03 \mathrm{fg}$ & $19.23 \mathrm{a}$ \\
\hline S1T1D1 & $\mathbf{3 8 . 7 7} \mathbf{g}$ & $27.17 \mathrm{c}$ \\
\hline S1T1D2 & $28.77 \mathrm{def}$ & $24.3 \mathrm{~b}$ \\
\hline S1T1D3 & $29.4 \mathrm{ef}$ & $33.97 \mathrm{e}$ \\
\hline S1T1D4 & $38.60 \mathrm{~g}$ & $30.43 \mathrm{~d}$ \\
\hline S1T1D5 & $26.77 \mathrm{def}$ & $34.1 \mathrm{e}$ \\
\hline S1T1D6 & $27.43 \mathrm{def}$ & $38.13 \mathrm{~g}$ \\
\hline S2T1D0 & $17.7 \mathrm{a}$ & $35.77 \mathrm{f}$ \\
\hline S2T1D1 & $18.97 \mathrm{ab}$ & $48.10 \mathrm{j}$ \\
\hline S2T1D2 & $24.37 \mathrm{def}$ & $42.33 \mathrm{~h}$ \\
\hline S2T1D3 & $22.67 \mathrm{def}$ & $46.43 \mathrm{i}$ \\
\hline S2T1D4 & $28.3 \mathrm{def}$ & $53.7 \mathrm{k}$ \\
\hline S2T1D5 & $28.7 \mathrm{def}$ & $54.27 \mathrm{k}$ \\
\hline S2T1D6 & $19.53 \mathrm{abc}$ & $62.17 \mathrm{l}$ \\
\hline S3T1D0 & $20.4 \mathrm{bcd}$ & 61.61 \\
\hline S3T1D1 & $21 \mathrm{cde}$ & $70.27 \mathrm{n}$ \\
\hline S3T1D2 & $28.7 \mathrm{def}$ & $67.13 \mathrm{~m}$ \\
\hline S3T1D3 & $20.7 \mathrm{cde}$ & $74.13 \mathrm{p}$ \\
\hline S3T1D4 & $24 \mathrm{def}$ & $70.33 \mathrm{n}$ \\
\hline S3T1D5 & $21.3 \mathrm{cde}$ & $71.73 \mathrm{o}$ \\
\hline S3T1D6 & $21.4 \mathrm{def}$ & $\mathbf{7 6 . 8 7 ~ q}$ \\
\hline
\end{tabular}

Noted: The number followed by the same letter in the same column shows that it is not significantly different at the level of $\alpha=5 \%$ with Duncan's continued test.

In this study, the application of $S i$ fertilizer caused the higher $S i$ uptake in rice biomass (grain + straw) compared to the control. Lack or sufficiency of Si in the soil is mainly determined by the speed at which it is filled in the soil solution and its absorption during plant growth. This is consistent with the statement of Jawahar \& Vaiyapuri (2013) that Si uptake in plants depends on the ability of the soil to supply Si [30].

The summary of $S i$ in general is that $S i$ fertilization can increase $S i$ availability when the $S i$ content is low in the soil. Si which is given through fertilization can increase the availability of $\mathrm{Si}$ in the soil and $\mathrm{Si}$ uptake in straw and grain [25].

\section{Conclusion}

1. Trass has a significant effect on the $S i$ content in the husk and $S i$ of the soil. Vertisols gave the highest number of panicles, namely 27 and $S i$ in straw at $12.75 \mathrm{mg} \mathrm{kg}^{-1}$.

2. Returning plant residues to the soil is very helpful in restoring or maintaining $S i$ in the soil.

\section{References}

1. [BPS] Badan Pusat Statistik. Kajian Konsumsi Bahan Pokok 2017. BPS RI. (2017)

2. E. Yasari, H. Yazdpoor, H.P. Kolhar, H.R. Mobasser. Effects of plant density and the application of silica on seed yield and yield components of rice (Oryza sativa L.). International Journal of Biology 4(4): 46-53. (2012)

3. Haynes RJ. A contemporary overview of silicon availability in agricultural soils. J 
Plant Nutr Soil Sci. 177: 831-844. (2014)

4. Husnain. Sumber Hara Silika untuk Pertanian. Warta Penelitian dan Pengembangan Pertanian, 33(3) : 12-13. (2011)

5. T.X. Cuong, H. Ullah, A. Datta, T.C. Hanh. Effects of silicon-based fertilizer on growth, yield and nutrient uptake of rice in tropical zone of Vietnam. Rice Science $\mathbf{2 4}$ (5): 283-290 (2017)

6. V.D. Meena, M.L. Dotaniya, Coumar Vassanda, S. Rajendiran, Ajay, S. Kundu, A. Rao Subba. A case for silicon fertilization to improve crop yields in tropical soils. Proc. Natl. Acad.Sci., 84 (3): 505-518. (2014)

7. G.C. Yan, M. Nikolic, M. Ye, Z. Xiao, Y. Liang. Silicon acquisition and accumulation in plant and its significance for agriculture. Journal of Integrative Agriculture 17 (10): 2138-2150. (2018)

8. T.X. Cuong, H. Ullah, A. Datta, T.C. Hanh. Effects of silicon-based fertilizer on growth, yield and nutrient uptake of rice in tropical zone of Vietnam. Rice Science 24(5): 283-290 (2017)

9. M. Amin, B. Nugroho, Suwarno, D.S. Tjahyandari. Response of Si Application and Its Nutrient Status in Rice. Jurnal Ilmu Pertanian Indonesia. 24(1), pp. 32-40. doi: 10.18343/jipi.24.1.32 (2019)

10. W. Zellner, J. Frantz, S. Leisner. Silicon delays Tobacco ringspot virus systemic symptoms in Nicotiana tabacum. J. Plant. Physiol. 168 (15): 1866- 1869. (2011)

11. Y.C. Liang, M. Nikolic, R. Belanger, H. Gong, A. Song. Silicon in agriculture: From theory to practice. Amsterdam (AMS): Springer (2015)

12. N. Sakr. The role of silicon $(\mathrm{Si})$ in increasing plant resistance against fungal diseases. Hellen Plant Protect. J. 9 (1): 1-15. (2016)

13. J. Cooke, J.L. Degabriel, S.E. Hartley. The functional ecology of plant silicon: geoscience to genes. Funct. Ecol. 30, 1270-1276. Doi: 10.1111/1365-2435.12711. (2016)

14. R. Deshmukh, R.R. Bélanger. Editorial: Role of silicon plants. Frontiers in Plant Sciences 8: 1858. (2017)

15. D. Coskun, R. Deshmukh, H. Sonah, J. G. Menzies, O. Reynolds, J. F. Ma. The controversies of silicon's role in plant biology. New Phytol. 221 (1), 67-85. doi: 10.1111/nph.15343 (2019)

16. D.F. Ning, A Song, F. L. Fan, Z. J. Li, Y. C. Liang. Effects of slag-based silicon fertilizer on rice growth and brown-spot resistance. PLoS One, 9: e102681 (2014)

17. J.L. Gong, H. C. Zhang, H. Y. Long, Y. J. Hu, Q. G. Dai, Z. Y. Huo. Progress in research of nutrition functions and physiological mechanisms of silicon in rice. Plant Physiology Journal 48:1-10 (2012)

18. S.S. Dara, R. Budihastuti, S.W.A. Suedy. Pengaruh pemberian pupuk nanosilika terhadap tinggi tanaman dan jumlah anakan padi beras merah (Oryza sativa L. var. indica).Buletin Anatomi dan Fisiologi 2 (2): 128-133 (2017)

19. R. Desmukh, R. R Belanger. Molecular evolution of equaporins and silicon influx in plants. Funct. Ecol. 30: 1277-1285 (2016)

20. R. W. Van Bemmelen. The Geology of Indonesia Vol II: Economy Geology. Hague (NL): Goverment Printing Office. (1949)

21. Fevi MP, Suedy SWA, Sri D. Pengaruh pupuk nanosilika terhadap jumlah stomata, kandungan klorofil dan pertumbuhan padi hitam (Oryza sativa L. cv. japonica). Buletin Anatomi dan Fisiologi. 2 (1). (2017) 
22. S. Wijitkosum, W. Kallayasiri. The use of biochar to increase productivity of indigenous upland rica (Oryza sativa) and improve soil properties. RJPBCS 6(2): 1326-1336 (2015)

23. Herviyanti. Perbaikan Sifat Kimia Oxisol Dengan Pemberian Bahan Humat dan Pupuk P Untuk Meningkatkan Serapan Hara dan Produksi Tanaman Jagung. Jurnal Solum Vol. 9, No. 2B. G. Rao, P. I Yadav, E. K. Syriac. 2017. Silicon nutrition in rice: a review. Jurnal of Pharmacogency and Phytochemistry 6(6): 390-392 (2012)

24. B. G. Rao, P. I. Yadav, E. K. Syriac. Silicon nutrition in rice: a review. Jurnal of Pharmacogencyand Phytochemistry 6(6): 390-392 (2017)

25. R. Swain, G.R. Rout. Effect of silicon interaction with nutrients in rice. Journal of Experimental Biology and Agricultural Sciences 6(4): 717-731 (2018)

26. Q. Liu, X. Zhou, Z. Sun. Application of silicon fertilizer affects nutritional quality of rice. Chilean Journal of Agricultural Research 77 (2): 163-170. (2017)

27. L. Anggria, Husnain, K. Sato, T. Masunaga. Release of silicon from silicate materials and its uptake by rice plant. Indonesian Journal of Agricultural Science 18(2): 69-76. (2017)

28. V.D. Meena, M.L. Dotaniya, V. Coumar, S. Rajendiran, Ajay, Kundu, A. Subba Rao. A case for silicon fertilization to improve crop yields in tropical soils. Proceedings of the National Academy of Sciences India Section B 84(30): 508-518. (2014)

29. N.A. Rebitanim, N.Z. Rebitanim, N.S. Tajudin. Impact of silicon in managing important rice disease: blast, sheath blight, brown spot and grain discoloration. IJAAR 6(3): 71-85 (2015)

30. S. Jawahar, V. Vaiyapuri. Effect of sulphur and silicon fertilization on yield, nutrient uptake, and economics of rice. International Research Journal of Chemistry 1:34-43 (2013) 